\section{Taquete SR, Borges L. Pesquisa qualitativa para todos. Petrópolis: Vozes; 2020.}

Wilza Vieira Villela

(https://orcid.org/0000-0002-6246-2716) ${ }^{1}$

${ }^{1}$ Medicina Preventiva, Universidade Federal de São Paulo. São Paulo SP Brasil.wilza.villela@gmail.com

Inspiradas por Cora Coralina, que num dado poema diz que não faz versos ou poesia, apenas conta velhas histórias de um modo diferente ${ }^{1}$, as autoras apresentam o volume Pesquisa qualitativa para todos anunciando a sua intenção: não fazer um tratado denso nem um manual de pesquisa qualitativa. Pretendem sim contar o que aprenderam sobre o tema ao longo dos vários anos como pesquisadoras e docentes em cursos de Pós-Graduação na Faculdade de Ciências Médicas da Universidade do Estado do Rio de Janeiro.

A busca por um caminho alternativo entre um tratado formal e um manual se justifica por duas razoes. A primeira considera a sua utilidade: estudantes da área de saúde, especialmente da área médica, nem sempre estão familiarizados com a leitura de textos teóricos ancorados nas ciências sociais e na filosofia que constituem a maioria dos tratados sobre o método. Ao mesmo tempo, a simplificação dos manuais por vezes incorre em reducionismos, comprometendo a densidade teórica necessária para que os resultados de uma investigação qualitativa não se confundam com conhecimentos produzidos pelo senso comum ${ }^{2}$. No afã de sintetizar os fundamentos teóricos do método qualitativo por vezes os manuais deixam de apresentar, na sua extensão e complexidade, as potencialidades do uso desta abordagem ${ }^{2}$. Perdem, assim a sua operacionalidade, pois nem sempre é simples seguir os passos descritos no manual, e muitas vezes a tentativa não resulta na produção de um conhecimento útil e inovador.

A segunda razão diz respeito ao posicionamento das autoras em relação ao diálogo e às trocas intersubjetivas. Inclusive é este posicionamento que determina a sua opção por uma abordagem que tem como um dos seus pressupostos a importância dos afetos, crenças e valores na produção de sentidos e significados das experiências para os sujeitos ${ }^{3}$.

Assim, escrever um livro sobre pesquisa qualitativa é, para as autoras, um meio de compartilhar sua experiência, incluindo escolhas e valores. Representa também um posicionamento de diálogo e troca, como leitor.

Nesta troca, as autoras buscam apresentar de forma simples e acessível, diferentes aspectos da investigação qualitativa. Dimensões teóricas, filosóficas e epistemológicas são discutidas e norteiam a exposição das dimensões mais técnicas e operacionais da utilização do método.

Contando "velhas histórias de um modo diferente" as autoras iniciam a conversa brindando o leitor com narrativas históricas sobre os modos de entender e interpretar o mundo, que mesmo baseados em lógicas bem distintas das que usamos hoje para explicar a vida, garantiram a sobrevivência e evolução da espécie ${ }^{4}$. Este percurso chega até a idade moderna, quando o conhecimento produzido pelo método científico se torna sinônimo de verdade. Entretanto, há vários pontos de parada, em teorias filosóficas ou das ciências sociais que buscam explicar as relações entre individuo e sociedade, a produção de subjetividades e sua objetivação. Sem pretender que seja um ponto de chegada, a narrativa compreende até reflexões mais práticas e atuais sobre o uso de softwares na pesquisa qualitativa.

Num primeiro momento, o jeito diferente de contar a velha história não é óbvio. Do mesmo modo que na pesquisa qualitativa, é preciso forçar um estranhamento para não tomar o discurso do outro como um já sabido.

No entanto, conforme se avança na leitura dos onze capítulos compõem o livro (e que podem ser lidos de forma independente, já que cada capítulo aborda um conteúdo específico) este jeito diferente de contar a velha história vai se desvelando. Os temas abordados são amplos e visam abarcar polos teóricos e técnicos, e os capítulos são encadeados de modo a evidenciar a indissociabilidade entre ambos; os conteúdos explorados em cada tema/capítulo também são amplos, juntando referencias tradicionais no campo a outras mais contemporâneas, locais e contextuais e, principalmente, reiterando a articular teoria e prática.

No decorrer da leitura vai se vislumbrando com mais nitidez as professoras frente aos seus alunos e as pesquisadoras frente aos seus interlocutores de pesquisa. Comprometidas com o aprendizado, a compreensão do outro e o compartilhamento das suas experiências, atentas a cada dúvida ou questionamento.

A escolha de apresentar os caminhos que conferiram sentido e significado à pesquisa qualitativa para as autoras captura o leitor. Não há uma oferta de soluções ou dicas para uso. As narrativas, reflexões, e sugestões esclarecem o leitor e instigam a sua curiosidade no sentido de aprofundar as referencias que dão suporte à abordagem qualitativa como estratégia válida para investigação científica na área da saúde.

O sujeito humano, alvo das práticas em saúde, se constitui como tal a partir da sua singularidade, formada por afetos, emoções, crenças e valores. Para
PESQUISA gualitativa ipARA TODOS

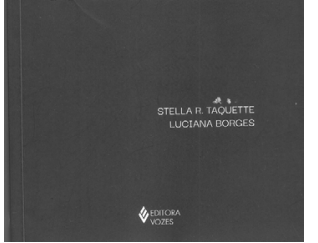


conhecê-lo são necessárias formas de objetivar sua subjetividade, o que é possível por meio das trocas intersubjetivas mediadas pelo uso da linguagem. Mas essas trocas precisam ser situadas e decodificas, para que a fala do sujeito se transforme na reverberação das falas/discursos dos vários sujeitos que habitam seu espaço social. As várias técnicas de produção e análise dos dados qualitativos, apresentadas pelas autoras correspondem à pluralidade de teorias apresentadas anteriormente, e à posição das autoras em oferecer um leque grande de possibilidades para que o leitor/pesquisador encontre a que lhe parece fazer mais sentido a cada momento/objeto de pesquisa.

$\mathrm{Na}$ área da saúde a delicada relação entre objetividade e subjetividade exige, mais que nunca, o uso de ferramentas conceituais e técnicas precisas para operar a transformação da fala de um sujeito num dado científico. A descrição objetiva do corpo humano e mensuração de cada aspecto do seu funcionamento é um requisito para as práticas terapêuticas. Nela se baseiam as intervenções clínicas. Entretanto, intervenções em saúde se dirigem a doenças- lesões ou disfunções, que ocorrem num sujeito, portador de uma história e de um universo afetivo singular. Mesmo a doença mais bem descrita nos tratados médicos adquire características particulares para cada sujeito que a vivência.

Ter ferramentas para compreender as dinâmicas subjetivas que delineiam processos de produção de saúde e de adoecimento amplia o escopo do trabalho e da pesquisa em saúde. Talvez por esta razão as autoras tenham sido tão criteriosas ao apresentar a perspectiva compreensiva da investigação qualitativa e a importância da subjetividade inerente ao humano, em qualquer processo de produção de conhecimento e no trabalho em saúde.

Lembretes simples, como o lugar da ciência no conjunto de saberes que orientam as decisões e práticas cotidianas dos sujeitos, ajudam a delimitar as potencialidades do uso do método. Explicações claras sobre as características do método o científico, demonstrando que sua especificidade não é a produção de verdades, e sim de consensos provisórios, contribuem para afirmar a cientificidade do método qualitativo e deixar o leitor com vontade de prosseguir a leitura. A apresentação de diferentes teorias oriundas das ciências sociais para fundamentar a escolha pela pesquisa qualitativa também é um recurso para ilustrar as várias possibilidades interpretativas de um mesmo evento, mais uma vez desfazendo a ideia de que a ciência produz verdades. E este arcabouço geral situa as orientações sobre as dimensões práticas da pesquisa. Ancorado numa perspectiva teórico-conceitual consistente, o passo a passo da pesquisa - definição e recorte do objeto, definição de referencial teórico e estratégias de produção e análise de dados, elaboração do projeto e escrita de relatório e artigos de divulgação dos resultados - não se transforma em receita para uso comum.

Do mesmo modo, a apresentação de estratégias de validação da pesquisa e seus resultados e a discussão sobre aspectos éticos da pesquisa qualitativa, não são um repertório de condutas a serem seguidos. Ao contrário, são reflexões e sugestões para que o leitor entre em diálogo a partir dos seus próprios valores e interesses e como pesquisador.

Um último ponto deve ser ressaltado, com respeito à persistência, principalmente entre aqueles que estão iniciando no mundo da pesquisa, de um suposto confronto entre métodos quantitativos e qualitativos. Trata-se de estratégias distintas, com finalidades diversas e, portanto, não passíveis de comparação. As autoras acertam em reconhecer que existe este tipo de querela, e acertam uma segunda vez em não entra nesta polêmica. A investigação qualitativa não pretende produzir verdades ou certezas, e sim desvendar a trama de sentidos que confere intelegibilidade às experiências ao sujeito situado histórica e culturalmente. A proposta de Taquette e Borges é fornecer elementos para aqueles que pretendem se aventurar nestes caminhos.

Ao apresentar múltiplas superfícies da investigação qualitativa as autoras dão valiosos subsídios para a compreensão e o uso dessa estratégia de produção de conhecimento. Mesmo que a mola propulsora para o livro tenha sido a experiência das autoras com estudantes e pós-graduandos da área da saúde o livro pode ser útil e interessante para qualquer pesquisador que queira ter uma visão ampla sobre a investigação qualitativa. Daí a feliz escolha do título: Pesquisa Qualitativa PARA TODOS.

\section{Referências}

1. Coralina C. Poemas dos becos de Goiás e estórias mais. São Paulo: Global Editora; 1984.

2. Denzin NK, Lincoln YS, editores. The Sage handbook of qualitative research. Thousand Oaks: Sage Publications; 2011.

3. Becker HS. Segredose truques da pesquisa. Rio de Janeiro: Zahar; 2007.

4. Harari YN. Sapiens: A brief history of humankind. Park Imperial: Random House; 2014. 